\title{
Autologous B-cell/Monocyte-presenting HER2/neu Antigen Vaccine BVAC-B
}

National Cancer Institute

\section{Source}

National Cancer Institute. Autologous B-cell/Monocyte-presenting HER2/neu Antigen

Vaccine BVAC-B. NCI Thesaurus. Code C156153.

An autologous vaccine composed of the antigen presenting cells (APCs) B-lymphocytes and monocytes presenting the tumor-associated antigen (TAA) human epidermal growth factor receptor type 2 (HER2/neu; HER-2; EGFR2; ErbB2). Upon administration of the autologous B-cell- and monocyte-presenting HER2/neu antigen vaccine BVAC-B, the APCs may stimulate the immune system to mount a HER2/neu-specific cytotoxic Tlymphocyte (CTL) immune response as well as a natural killer (NK) cell, and antibodymediated immune response against HER-2/neu-positive tumor cells, which may result in tumor cell death and decreased tumor growth. HER-2, a tyrosine kinase receptor for epidermal growth factor (EGF), is overexpressed by a variety of tumors. 